\title{
BIOMASS CARBON CONTENT IN SCHIMA-CASTANOPSIS FOREST OF MIDHILLS OF NEPAL: A CASE STUDY FROM JAISIKUNA COMMUNITY FOREST, KASKI
}

\author{
Sushma Tripathi, C.B Thapa, Amrit Sharma* \\ Department of Botany, PN Campus, TU, Pokhara \\ *Department of National Parks and Wildlives Reserve, Gaurishankar Conservation Office, Dolakha
}

\begin{abstract}
Forests are considered as both the source and sinks of carbon. Different types of forests have different carbon stock. Nepal's midhills community forests have high potentiality to sequester carbon. This paper analyzes the biomass carbon stock in Schima-Castanopsis forest of Jaisikuna community forests of Kaski district, Nepal. Forest area was divided into two blocks and 18 sample plots (9 in each block) were laid randomly. Diameter at Breast Height $(\mathrm{DBH})$ and height of trees $(\mathrm{DBH} \geq 5 \mathrm{~cm})$ were measured using the DBH tape and clinometer. Leaflitter, herbs, grasses and seedling were collected from $1^{*} 1 \mathrm{~m}^{2}$ plot and fresh weight was taken. Biomass of tree was calculated and below ground biomass is assumed $15 \%$ of above ground tree biomass. For calculating carbon stock, biomass is multiplied by default value 0.47 . The above ground tree biomass (AGTB) carbon of chilaune, katus and other species was found $19.56 \mathrm{t} / \mathrm{ha}, 18.66 \mathrm{t} / \mathrm{ha}$ and $3.59 \mathrm{t} / \mathrm{ha}$ respectively. The AGTB of chilaune dominated, katus dominated and whole forest was found $43.78 \mathrm{t} / \mathrm{ha}, 39.83 \mathrm{t} / \mathrm{ha}$ and $41.81 \mathrm{t} /$ ha respectively. LHG carbon was found $2.73 \mathrm{t} / \mathrm{ha}$. Below ground biomass carbon at whole forest was found $6.27 \mathrm{t} / \mathrm{ha}$ respectively. Total biomass and carbon at forest was found $108.09 \mathrm{t} / \mathrm{ha}$ and $50.80 \mathrm{t} /$ ha respectively. Difference in biomass and carbon content at chilaune dominated block and katus dominated block was found insignificant. Carbon estimation at forest of different elevation, aspect and location are recommended for further research.
\end{abstract}

Keywords : Biomass, carbon content, climate change, Kaski

\section{INTRODUCTION}

Climate change is evident (Karl and Trenberth, 2003; Trenberth, 2011) in many respects. Recently published report of Intergovernmental Panel on Climate Change (IPCC 2013) showed that global temperature has increased by 0.85 ${ }^{\circ} \mathrm{C}$ over the period from 1880 to 2012 (IPCC, 2013). Increasing concentration of Greenhouse Gases (GHGs) in the atmosphere is responsible for anthropogenic climate change. Carbondioxide $\left(\mathrm{CO}_{2}\right)$ is one of the major green house gases (GHGs) contributing to global warming. Concentration of $\mathrm{CO}_{2}$ in atmosphere increased by $40 \%$ since pre-industrial time and reached
$391 \mathrm{ppm}$ in 2011 (IPCC, 2013).To deal with climate change we need to reduce emission and enhance sink of GHGs which the United Nations Framework Convention on Climate Change (UNFCCC) recognized. The main objective of the UNFCC is to stabilize the concentration of GHGs in the atmosphere at the level to allow ecosystem to adapt naturally (UNFCCC, 1992). Different sinks and sources of GHGs are identified to deal with the increasing GHG concentration in the atmosphere of which forests are the efficient carbon sinks.

Forests are crucial ecosystem for maintaining the global carbon balance as about $80 \%$ of all above 
ground and $40 \%$ of all below ground terrestrial organic carbon is stored in forests (IPCC, 2001). Forests play vital role in both carbon sequestration and storage and are considered as important component of global carbon cycle(Candell and Raupach, 2008). Forests sequester large amounts of carbon annually (Bonan, 2008) and considered important natural "brakes" to climate change (Gibbs et al, 2007). The trees sequester atmospheric carbon through photosynthesis and store it in the form of wood biomass (Brown and Pearce, 1994). World's forests and forest soils currently store more than 1 trillion tonnes of carbon, nearly double amount of carbon floating free in the atmosphere (Oli and Shrestha, 2009). After long discussion, the link between forests and climate change was acknowledged at the $13^{\text {th }}$ Conference of Parties to UNFCCC at 2007 (Dhital, 2009).

Nepal is moving to participate in the internal carbon trading mechanism, Reducing Emission through Deforestation and Forest Degradation (REDD+). To participate in the REDD+ mechanism it is urgently needed to estimate the carbon content and sequestration rate of different forest types of Nepal. Community forestry is the major forest regime in midhills managing the forest resources. Community forestry has been recognized as a successful program for managing the forest resources (Paudel 2014;2015). Community forest user groups are involved in climate change adaptation (Acharya and Paudel, 2016) and its forest have huge potential to mitigate through carbon sequestration.

Carbon stock of community forest depends on climatic conditions, soil type, landscape, altitude, aspect, species, density of stands and forest age (Shrestha and Singh, 2008).Various spatial and temporal factors including forest type, size, age, stand structure, associated vegetation and ecological zonation are determinants of carbon storage in forest (Karki et al, 2016).Schima wallichii (Chilaune) and Castanopsis species (Katus) are the dominant tree species at midhills of Nepal. Schima wallichii and Castanopsis species constitute about $2.66 \%$ and $1.73 \%$ of total stem volume of Nepal (DFRS, 2015). There is higher variation in past studies (Khanal, 2008; Shrestha, 2009; Aryal, 2010; Neupane and Sharma, 2014; Pandit, 2014) regarding to carbon content in Schima-Castanopsis forest. The inconsistent findings indicate the higher level of variability and uncertainty in carbon sequestration in Schima-Castanopsis forest. Thus the previous studies about the carbon sequestration of Schima-Castanopsis forest of midhills are inadequate to characterize the carbon sequestration in these forests.More detail studies are needed to get better estimate of carbon sequestration in community managed forests (Bhattarai et al, 2012). The main carbon pools in forests are the living biomass of trees and understory vegetation and the dead mass of litter, woody debris and soil organic matter of which above ground biomass is important from the perspectives of deforestation and degradation (Gibbs et al, 2007). In this regard, this study aims to estimate the carbon content in biomass of Schima-Castanopsis forest in a midhill community forest.

\section{MATERIALS AND METHODS}

\section{Study Area}

This study was carried out in Jaisikuna Community Forest of Pokhara Lekhnath Metropolitian city-29 (previously Hemja VDC) of Kaski district.. The brief information of Jaisikuna community forest is presented in Table 1.

Table 1: Brief Information of Jaisikuna CF

\begin{tabular}{|l|l|}
\hline Total area & $19.00 \mathrm{ha}$ \\
\hline Forest type & $\begin{array}{l}\text { Schima-Castanopsis } \\
\text { forest }\end{array}$ \\
\hline
\end{tabular}




\begin{tabular}{|l|l|}
\hline Forest condition & Medium \\
\hline Total household & 95 \\
\hline $\begin{array}{l}\text { Total population of } \\
\text { user group }\end{array}$ & 863 \\
\hline Soil type & $\begin{array}{l}\text { Silty loam and silty clay } \\
\text { loam }\end{array}$ \\
\hline Aspect & North east \\
\hline $\begin{array}{l}\text { Major forest } \\
\text { species }\end{array}$ & $\begin{array}{l}\text { Schima wallichii (Chilaune) } \\
\text { and Castanopsis indica } \\
\text { (Katus) }\end{array}$ \\
\hline Other species & $\begin{array}{l}\text { Myrica esculenta, Myrsie } \\
\text { capitellata Holarrhena } \\
\text { pubescens, Engelhardia } \\
\text { spicata, } \text { Rhododendron } \\
\text { arboretum }\end{array}$ \\
\hline
\end{tabular}

(Source: Jaisikuna Community Forest)

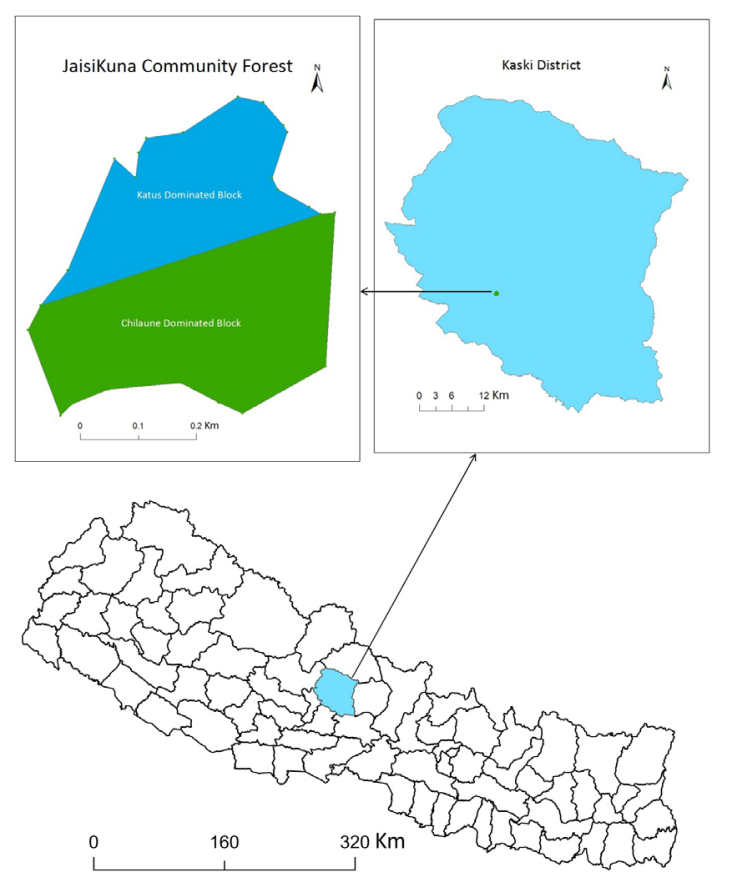

Figure 1: Studied Community Forest

\section{Sampling}

Total forest area is divided into two blocksviz. Chialune dominated and Katus dominated forest. Sampling procedures mentioned in Carbon measurement guideline (MFSC, 2011) formulated by the REDD implementation center was employed for data collection. Sample plots were taken at $10 \%$ sampling intensity on each block. Total 18 sample plots (9 in chilaune dominated block and 9 in katus dominated block) were established randomly for the field data collection. The rectangular plots of size $20 \times 25 \mathrm{~m}^{2}, 10 \times 10 \mathrm{~m}^{2}, 5 \times 5 \mathrm{~m}^{2}$ were laid down for the tree, pole and sapling respectively at the corner of each plot. Litter, herbs and grass including seedling (LHG) were collected from the $1 \times 1 \mathrm{~m}^{2}$ laid down as nested plot.

\section{Data Collection}

The Diameter at Breast Height (DBH) of individual tree $(\mathrm{DBH} \geq 5 \mathrm{~cm})$ was measured by diameter tape and the height was measured by using a clinometer. All the LHG were collected and the fresh weight was taken in the field. The samples of LHG were placed in the marked sample bag and dried in the laboratory to determine the oven dry weight of the biomass.

\section{Data analysis}

Obtained data were fed into Ms-Excel and Statistical Package for Social Sciences (SPSS). Biomass and carbon content was estimated by using the following formulae.

\section{Above ground tree carbon stock (AGTB)}

Allometric equation developed by Chave et al. (2005) for moist forest stand was used to estimate above ground tree (tree, pole and sapling) biomass. Obtained value of biomass was multiplied by the IPCC (2006) default carbon fraction of 0.47 to estimate carbon content. $\mathrm{AGTB}=0.0509 \rho \times \mathrm{D}^{2} \mathrm{H}$

Where,

AGTB $=$ above ground tree biomass $(\mathrm{kg})$

$$
\begin{aligned}
& \rho=\text { dry wood density }\left(\mathrm{gm} / \mathrm{cm}^{3}\right) \\
& D=\text { tree diameter at breast height }(\mathrm{cm}) \\
& H=\text { tree height }(\mathrm{m})
\end{aligned}
$$

\section{Under ground Biomass Carbon Stock}

Underground biomass carbon stock was 
calculated assuming $15 \%$ of the above ground tree biomass carbon stock.

\section{Leaf litter, herb and grass (LHG) carbon stock}

LHG includes litter, herbs, grass and seedling. The amount of biomass per unit area was calculated by:

LHG $=\mathrm{W}$ (field) $/ \mathrm{A} \times \mathrm{W}($ dry subsample $) / \mathrm{W}$ (wet sub sample) $\times 10$

Where,

LHG = biomass of leaf litter, herbs and grass ( $\mathrm{t} /$ ha)

$\mathrm{W}$ (field) = weight of the fresh field sample of leaf litter, herbs, grass and sapling destructively sample within an area of size A (gm)

$A=$ size of the area in which leaf litter, herbs, grass and sapling were collected (ha)

$\mathrm{W}($ dry subsample $)=$ weight of the oven dry sub sample of leaf litter, herbs, grass and seedling taken to the laboratory to determine moisture content (gm)

$\mathrm{W}$ (wet subsample) $=$ weight of the fresh sub sample of leaf litter, herbs, grass and seedling taken to the laboratory to determine moisture content (gm)

The carbon content in LHG, C (LHG) was calculated by multiplying LHG biomass by 0.47 the default carbon fraction (IPCC, 2006).

Then total biomass carbon stock was estimated by adding up the value of all the biomass carbon pool. Total Biomass Carbon Stock (TBCS) $=$ AGTB (carbon) + Below ground (carbon) + LHG (carbon)

Analysis of variance (ANOVA) and t-test have been used to test the significance of different of mean biomass and mean biomass carbon content.

\section{RESULTS AND DISCUSSION}

\section{Above Ground Tree Biomass and Carbon}

The AGTB of katus (59.59 t/ha) was found highest in katus dominated block followed by AGTB of chilaune (19.73 t/ha) (Figure 2). Likewise in chilaune dominated forest, AGTB of chilaune was highest $(63.50 \mathrm{t} / \mathrm{ha})$ followed by AGTB of katus (19.81 t/ha). In whole forest AGTB of chilaune, katus and other species was found $41.62 \mathrm{t} / \mathrm{ha}, 39.70 \mathrm{t} / \mathrm{ha}$ and $7.63 \mathrm{t} / \mathrm{ha}$ respectively. The AGTB of chilaune dominated block, katus dominated block and whole forest was found $93.16 \mathrm{t} / \mathrm{ha}, 84.74 \mathrm{t} / \mathrm{ha}$ and $88.95 \mathrm{t} / \mathrm{ha}$ respectively. Analysis of Variance (ANOVA) shows that the mean AGTB of species differs significantly in katus dominated block $(\mathrm{F}=52.25, \mathrm{p}=0.000)$, chilaune dominated forest $(\mathrm{F}=23.87, \mathrm{p}=0.000)$ and in whole forest $(\mathrm{F}=12.65, \mathrm{p}=0.000)$. Khanal (2008) in SchimaCastanopsis forest at Palpa district found the aboveground tree biomass as $82.6 \pm 7.8 \mathrm{t} /$ ha.which was slightly lower than our findings. The AGTB was found $76.65 \mathrm{t} / \mathrm{ha}$ and $91.77 \mathrm{t} /$ ha in Schima-Castanopsis forest at 1100-1200 and 1350-1500 elevation respectively (Shrestha, 2009). Neupane and Sharma (2014) reported 117.213 t/ha and 299.615 t/ha AGTB in Laxmi mahila and Jalbire mahila community forests in Gorkha district. Pandit (2014) reported the higher AGTB biomass (555.99 t/ha) in midhills community forests of Nepal.

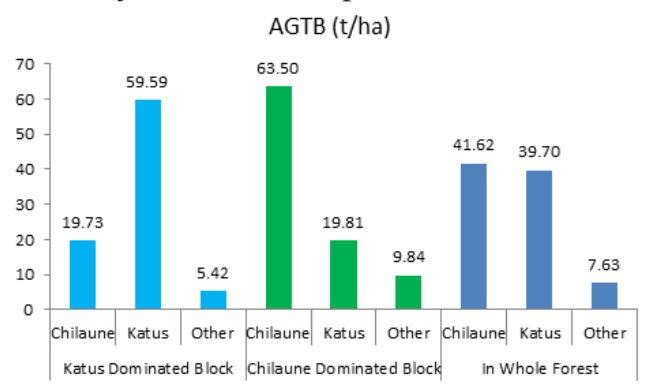

Figure 2: Above Ground Tree Biomass (AGTB) in different blocks

The AGTB carbon of katus $(28.01 \mathrm{t} / \mathrm{ha})$ was found highest in katus dominated block followed by AGTB carbon of chilaune (9.27 t/ha) (Figure 
3). Likewise in chilaune dominated block AGTB carbon of chilaune was highest (28.85 t/ha) followed by AGTB carbon of katus (9.31 t/ha). In whole forest AGTB carbon of chilaune, katus and other species was found to be $19.56 \mathrm{t} / \mathrm{ha}$, $18.66 \mathrm{t} /$ ha and $3.59 \mathrm{t} /$ ha respectively. The AGTB carbon of chilaune dominated, katus dominated and whole forest was found $43.78 \mathrm{t} / \mathrm{ha}, 39.83$ $\mathrm{t} /$ ha and $41.81 \mathrm{t} / \mathrm{ha}$ respectively. Analysis of Variance (ANOVA) shows that the mean AGTB carbon of species differs significantly in katus dominated block $(\mathrm{F}=52.25, \mathrm{p}=0.000)$, chilaune dominated forest $(\mathrm{F}=23.87, \mathrm{p}=0.000)$ and in whole forest $(\mathrm{F}=12.65, \mathrm{p}=0.000)$. Findings on AGTB carbon of the study is higher than the study carried out by Baral et al (2009). Baral et al (2009) reported AGTB and total above ground carbon stock as $76.24 \mathrm{t} / \mathrm{ha}$ and $34.30 \mathrm{t} / \mathrm{ha}$ respectively of Schima-Castanopsis forest. The AGTB carbon stock was found $32.91 \mathrm{t} / \mathrm{ha}$ and $39.46 \mathrm{t} /$ ha in Schima-Castanopsis forest at 1100$1200 \mathrm{~m}$ and 1350-1500m elevation respectively. Pandit (2014) reported the higher AGTB carbon (250.66 t/ha) in a community forest of Kaski district. Neupane and Sharma (2014) reported $50.401 \mathrm{t} /$ ha and $128.834 \mathrm{t} / \mathrm{ha}$ AGTB carbon in Laxmi mahila and Jalbire mahila community forests in Gorkha district.Aryal (2010) in his carbon assessment at the Sipadol Community forest in Bhaktapur found Carbon stock in Schima-Castanopsis forest $31.4 \mathrm{t} / \mathrm{ha}$.

\section{Leaf litter, Herbs, Grasses and Seedling Biomass and Carbon}

The LHG biomass and carbon was found slightly higher in Chilaune dominated block (biomass $=6.05 \mathrm{t} / \mathrm{ha}$, carbon $=2.84 \mathrm{t} / \mathrm{ha}$ ) than the katus dominated block (biomass $=5.54 \mathrm{t} / \mathrm{ha}$, carbon $=2.61 \mathrm{t} / \mathrm{ha}$ ) (Figure 4$)$. LHG biomass and carbon at whole forest was found $5.80 \mathrm{t} / \mathrm{ha}$ and $2.73 \mathrm{t} /$ ha respectively. Neupane and Sharma (2014) reported the similar results in Laxmi mahila (biomass $=5.81$ and carbon $=2.501 \mathrm{t}$ / ha) and Jalbiremahila (biomass $=6.295 \mathrm{t} / \mathrm{ha}$ and carbon $=2.707 \mathrm{t} / \mathrm{ha}$ ) community forests in Gorkha district. There is very much variation in LHG biomass and carbon which is also affected by the leaf litter collection practice in Nepal's forest. In contrast to our findings, LHG biomass and carbon was found $3.75 \mathrm{t} / \mathrm{ha}$ and $1.61 \mathrm{t} / \mathrm{ha}$ respectively which at Schima-Castanopis forest of 1100-1200 m elevation (Shrestha, 2009). Likewise Pandit (2014) reported 1.725 t/ha LHG carbon in community forest of Kaski district.

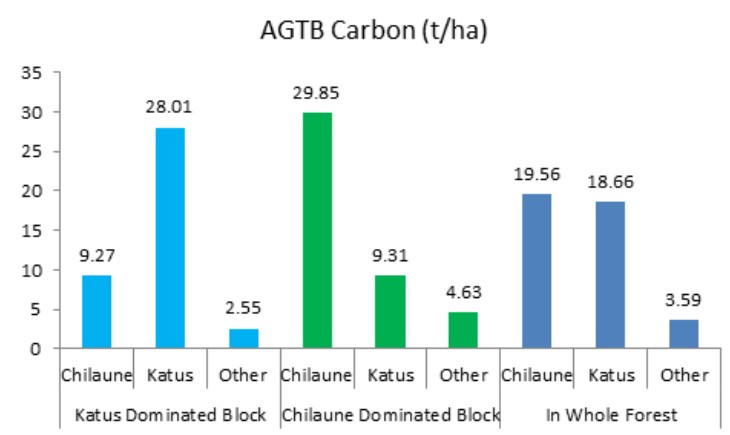

Figure 3: Above Ground Tree Biomass (AGTB) carbon in different blocks

LHG Biomass and Carbon (t/ha)

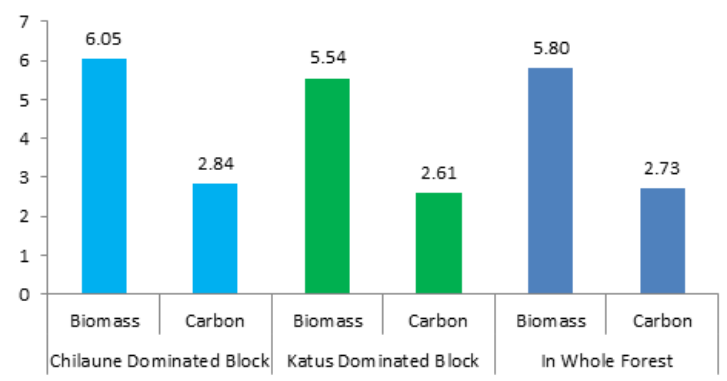

Figure 4: LHG biomass and carbon in different blocks

\section{Below Ground Biomass and Carbon}

The below ground biomass and carbon was found slightly higher in Chilaune dominated block (biomass $=13.98 \mathrm{t} / \mathrm{ha}$, carbon $=6.57 \mathrm{t} / \mathrm{ha}$ ) than the Katus dominated block (biomass $=12.71$ $\mathrm{t} / \mathrm{ha}$, carbon $=5.97 \mathrm{t} / \mathrm{ha})($ Figure 5). Below 
ground biomass and carbon at whole forest was found $13.34 \mathrm{t} / \mathrm{ha}$ and $6.27 \mathrm{t} / \mathrm{ha}$ respectively. Root biomass was found $22.99 \mathrm{t} / \mathrm{ha}$ and 27.53 t/ha in Schima-Castanopsis forest of 1100$1200 \mathrm{~m}$ and $1350-1500 \mathrm{~m}$ elevation respectively (Shrestha, 2009). Shrestha (2009) also reported that carbon in root was $9.88 \mathrm{t} / \mathrm{ha}$ and $11.83 \mathrm{t} / \mathrm{ha}$ in $1100-1200 \mathrm{~m}$ and $1350-1500 \mathrm{~m}$ respectively. Pandit (2014) reported 50.135 t/ha underground biomass carbon which is very much higher than our finding.

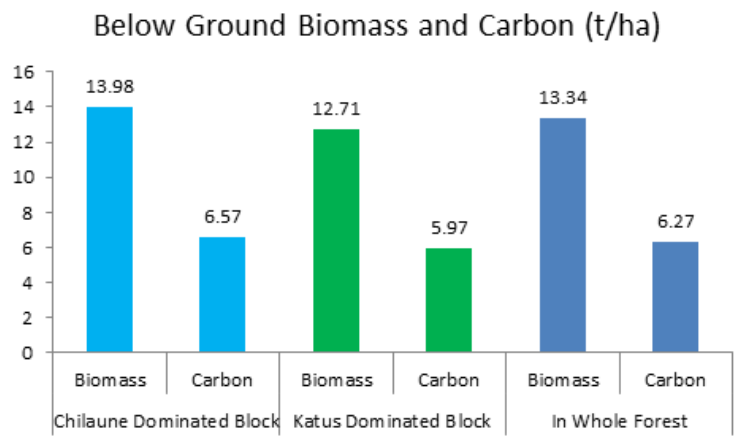

Figure 5: Below ground biomass and carbon in different blocks

\section{Total Biomass and Carbon}

The total biomass and carbon was found slightly higher in Chilaune dominated block (biomass $=113.18 \mathrm{t} / \mathrm{ha}$, carbon $=53.20 \mathrm{t} / \mathrm{ha}$ ) than the katus dominated block (biomass $=103.00 \mathrm{t} /$ ha, carbon $=48.41 \mathrm{t} / \mathrm{ha}$ ) $($ Figure 6$)$. Total biomass and carbon at whole forest was found $108.09 \mathrm{t} / \mathrm{ha}$ and $50.80 \mathrm{t} /$ ha respectively. Mean carbon content on chilaune dominated block was not found significantly different with the katus dominated forest $(\mathrm{t}$-value $=0.6597, \mathrm{p}=0.5228$ ) (Table 2). Our finding on total biomass carbon was similar with the findings of Shrestha (2009). He reported $52.32 \mathrm{t} / \mathrm{ha}$ and $47.9 \mathrm{t} / \mathrm{ha}$ total biomass carbon at Schima-Castanopsis forest of $1100-1200 \mathrm{~m}$ and 1350-1500m elevation respectively. In contrast to our finding, Pandit (2014) estimated 302.004 t/ha total biomass carbon. Level of human disturbance and management intervention largely determines the carbon content. The variation in carbon content in different studies could be due to difference in disturbance and management intervention. Our finding is consistent with the findings of most of the studies conducted in the Schima-Castanopsis forest of midhills of Nepal. The variation in carbon content suggest us to conduct more studies about carbon content of forest having different biophysical condition and disturbance and management intervention.

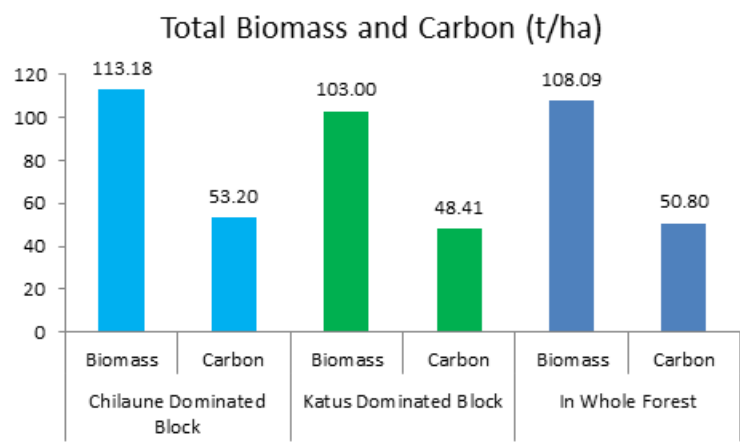

Figure 6: Total biomass and carbon in different blocks

Table 2: Results of t-test to test equality of mean carbon content in Chilaune and Katus dominated block

\begin{tabular}{|l|l|l|}
\hline Categories & t-value & sig. \\
\hline AGTB carbon & 0.6210 & 0.5468 \\
\hline LHG carbon & 0.6896 & 0.5004 \\
\hline Underground carbon & 0.6226 & 0.5458 \\
\hline Total carbon & 0.6597 & 0.5228 \\
\hline
\end{tabular}

\section{CONCLUSIONS}

AGTB of Chilaune, Katus and other species was found $41.62 \mathrm{t} / \mathrm{ha}, 39.70 \mathrm{t} / \mathrm{ha}$ and $7.63 \mathrm{t} / \mathrm{ha}$ respectively. Biomass and carbon content at Chilaune dominated block was slightly higher than that of the Katus dominated forest although the difference was not significant. Total biomass and carbon was found $108.09 \mathrm{t} / \mathrm{ha}$ and $50.80 \mathrm{t} /$ ha respectively. The variation of the findings on the carbon content of the different studies 
Biomass Carbon Content in Schima-Castanopsis ... suggests that there is high variation in forest condition and resulting carbon sequestration in Nepal's forest. Carbon estimation of SchimaCastanopsis forest in different elevation, aspect and region is recommended for further research to better understand the carbon sequestration dynamics of Schima-Castanopsis forest.

\section{ACKNOWLEDGEMENT}

We extend our thanks to the Department of Botany, PN Campus for providing laboratory facilities.

\section{REFERENCES}

Acharya, R. and G. Paudel (2016). Implementation status of community adaptation plans: a case study from Parbat District, Nepal. International Journal of Environment, 5(3): 119-126.

Aryal, C., (2010). Status of carbon Stock at Toudol Chhap Community Forest, Sipadol, Bhaktapur. A Thesis Submitted to the Central Department of Environmnetal Science, Tribhuvan University.

Baral, S.K., R. Malla, and S. Ranabhat (2009). Above-ground carbon stock assessment in different forest types of Nepal. Banko Janakari, 19(2): 10-14.

Bhattarai, T., M. Skutsch, D. Midmore, and E.B. Rana (2012). The carbon sequestration potential of community based forest management in Nepal. International journal of climate change, 3(2), pp.233-254.

Bonan, G. B., (2008). Forests and climate change: forgings, feedbacks, and the climate benefits of forests. science, 320 (5882): 1444-1449.

Brown, K. and D.W. Pearce, (1994). The causes of tropical deforestation: the economic and statistical analysis of factors giving rise to the loss of the tropical forests. UBC Press.

Canadell, J.G. and M.R., Raupach (2008). Managing forests for climate change mitigation. Science, 320 (5882): 1456-1457.

Chave, J., C. Andalo, S. Brown, M.A. Cairns, J.Q. Chambers, D. Eamus, H. Fölster, F. Fromard, N. Higuchi, T. Kira, and J.P. Lescure, (2005). Tree allometry and improved estimation of carbon stocks and balance in tropical forests. Oecologia, 145(1): 87-99.

DFO, (2017). Annual Monitoring and Evaluation Report of Community Forests of Kaski District. District Forest Office, Kaski, Nepal.

DFRS, (2015). State of Nepal's Forests. Forest Resource Assessment (FRA) Nepal, Department of Forest Research and Survey (DFRS). Kathmandu, Nepal.

Dhital, N., (2009). Reducing emissions from deforestation and forest degradation (REDD) in Nepal: exploring the possibilities. Journal of Forests and Livelihoods, 8(1): 57-62.

Gibbs, H.K., S. Brown, J.O. Niles, and J.A. Foley, (2007). Monitoring and estimating tropical forest carbon stocks: making REDD a reality. Environmental Research Letters, 2(4): 1-13.

IPCC, (2001). Climate Change (2001): The scientific basis. Working Group I. New York, USA: Cambridge University Press

IPCC, (2006).Guidelines for National Green house Gas Inventories. Intergovernmental Panel on Climate Change (IPCC), Geneva, Switzerland.

IPCC, (2013). Summary for Policymakers. In: Climate Change 2013: The Physical Science Basis. Contribution of Working Group I to the Fifth Assessment Report of the Intergovernmental Panel on Climate Change [Stocker, T.F., D. Qin, G.-K. Plattner, M. Tignor, S.K. Allen, J. Boschung, A. Nauels, Y. Xia, V. Bex and P.M. Midgley (eds.)]. Cambridge University Press, Cambridge, United Kingdom and New York, USA. 
Karki, S., N.R. Joshi, E. Udas, M.D. Adhikari, S. Sherpa, R. Kotru, B.S. Karky, N. Chettri, and W. Ning, (2016). Assessment of forest carbon stock and carbon sequestration rates at the ICIMOD Knowledge Park at Godavari. ICIMOD Working Paper 6:1-39.

Karl, T.R. and K.E. Trenberth, (2003). Modern global climate change. science, 302(5651): 1719-1723.

Khanal, Y., (2008). Valuation of carbon sequestration and water supply services in community forests of Palpa district, Nepal. A thesis submitted for the partial fulfillment of the requirements of the Master's degree of Science in Forestry, Tribhuvan University, Institute of Forestry, Pokhara, Nepal.

MFSC, (2011). Forest Carbon Measurement Guideline. Ministry of Forest and Soil Conservation, REDD Forestry and Climate Change Cell, Kathmandu, Nepal.

Neupane, B. and R. P. Sharma, (2014). An assessment of the effect of vegetation size and type, and altitude on above ground plant biomass and carbon. Journal of Agricultural and Crop Research, 2(3): 44-50.

Paudel, G., (2014). Analysis of equity, poverty and sustainability aspects of community forests of Nepal. VIKAS (A Journal of Development), 36(1): 89-96.

Paudel, G., (2015). Forest resource income variation in mid-hills of Nepal: a case study from two CFUGs of Parbat district, Nepal. International Journal of Environment, 4(3): 1-10.
Oli, B.N. and K. Shrestha (2009). Carbon status in forests of Nepal: an overview. Journal of Forest and Livelihood, 8(1): 62-66.

Pandit, S., (2014). Comparative assessment of carbon stock of Annapurna Conservation Area with khahati khola kaule pani community forest, Kaski. Thesis submitted to College of Applied Sciences-Nepal (Affiliated to Tribhuvan University) as the partial fulfillment of the requirement for the Master of Science degree in Environmental Sciences of Tribhuvan University.

Shrestha, B. P., (2009). Carbon sequestration in Schima-Castanopsis forest: A case study from Palpa District. The Greenery-A Journal of Environment and Biodiversity, 7(1): 3440.

Trenberth, K.E., (2011). Changes in precipitation with climate change. Climate Research, 47 (1/2): 123-138.

UNFCCC, (1992). The United Nations Framework Convention on Climate Change (UNFCCC) Convention text.

(Received 18 Sept 2017, revised accepted 23 Oct 2017) 